\title{
ОРГАНІЗАЦІЯ УПРАВЛІНСЬКОГО ОБЛІКУ В БЮДЖЕТНИХ УСТАНОВАХ
}

\author{
Луцький національний технічний університет
}

Діяльність бюджетних установ має свої особливості, які зумовлюють відповідну специфіку нормативного забезпечення облікового процесу в установах державного сектору. Метою написання статті $\epsilon$ проведення аналізу нормативно-правового забезпечення облікового процесу господарської діяльності бюджетних установ.

Нормативне забезпечення обліку - це комплекс нормативно-правових документів, які встановлюють єдині вимоги до ведення обліку у бюджетних установах.

Нормативна база $є$ сукупним відображенням соціального, політичного, економічного, міжнародного впливів. У роботі розглянуто розвиток бюджетного обліку у 20-21 столітті. Виникнення різних форм власності після 1991 року призвело до суттєвих реформаційних процесів у бюджетному обліку.

Нормативно-правове забезпечення обліку у бюджетних установах можна поділити на три рівні: вищий рівень - регулює діяльність всіх суб'єктів господарювання, незалежно від форми власності; середній рівень - характеризується нормативним забезпеченням обліку діяльності установ державного сектору економіки; нижчий рівень - визначає перелік нормативів, які розроблені і функціонують виключно для забезпечення діяльності конкретної установи.

Основою ведення обліку є базові нормативи, які прийняті основним законодавчим органом України і визначають правові засади функціонування суб'єктів господарювання різних форм власності. Сюди відноситься Конституція України, Господарський Кодекс України, Цивільний Кодекс України, Трудовий Кодекс України, Кодекс про адміністративні правопорушення, Податковий Кодекс України. У цій нормативній ланці важливо виділити, Бюджетний кодекс України та Закон України «Про Про бухгалтерський облік та фінансову звітність в Україні».

Середній рівень нормативно-правового забезпечення включає у себе нормативні акти, які визначають методику обліку активів, пасив та господарських процесів у бюджетних установах.

Ознайомлення практикуючого бухгалтера $з$ нормативами вищої і середньої ланок дає базові знання щодо діючої методики обліку у бюджетних установах. Але кожна бюджетна установа має свої особливості у побудові облікового процесу. Керівник бюджетної установи затверджує пакет внутрішніх документів, які визначають правила функціонування цієї установи: штат працівників та посадові оклади, форма оплати праці, посадові обов'язки штатних працівників, облікова політика бюджетної установи. Слід зазначити, що керівник бюджетної установи формує свою облікову політику у відповідності до діючого законодавства.

Нормативна база з обліку в бюджетних установах знаходиться у процесі реформування і постійних змін. Зміни зумовлені глобалізаційними процесами, які відбуваються у світі та прагненням України приєднатися до них.

Ключові слова: бюджетна установа, державний сектор, нормативно-правове забезпечення обліку.

\section{ASSESSMENT OF REGULATORY AND LEGAL SUPPORT OF ACCOUNTING OF ECONOMIC ACTIVITY OF BUDGET INSTITUTIONS}

\author{
Lutsk National Technical University
}

The activity of budgetary institutions has its peculiarities, namely: they are a component of the budget system of Ukraine; carry out activities on the rights of state or communal property; the purpose of the activity is not to make a profit; receive financial resources from the budgets of the respective levels; the financial condition of the budgetary institution is determined by the adequacy and timeliness of financial resources from the budgets of the respective levels.

These features determine the corresponding specifics of the regulatory support of the accounting process in public sector institutions.

Regulatory support of accounting is a set of legal documents that establish uniform requirements for accounting in budgetary institutions.

The regulatory framework is a collective reflection of social, political, economic, international influences. The paper considers the development of budget accounting in the 20-21 century. The emergence of various forms of ownership after 1991 has led to significant reform processes in budget accounting. 
Regulatory and legal support of accounting in budgetary institutions can be divided into three levels: higher level - regulates the activities of all business entities, regardless of ownership; middle level - is characterized by regulatory support for accounting of public sector institutions; lower level - determines the list of standards that are developed and operate solely to ensure the activities of a particular institution.

The basis of accounting is the basic standards adopted by the main legislative body of Ukraine and determine the legal basis for the operation of economic entities of various forms of ownership. These include the Constitution of Ukraine, the Commercial Code of Ukraine, the Civil Code of Ukraine, the Labor Code of Ukraine, the Code of Administrative Offenses, the Tax Code of Ukraine. In this normative link, it is important to highlight the Budget Code of Ukraine and the Law of Ukraine «On Accounting and Financial Reporting in Ukraine».

The average level of regulatory support includes regulations that determine the methodology of accounting for assets, liabilities and business processes in budgetary institutions.

Familiarization of a practicing accountant with the standards of higher and middle levels provides basic knowledge about the current methods of accounting in budgetary institutions. But each budgetary institution has its own peculiarities in the construction of the accounting process. The head of the budget institution approves a package of internal documents that define the rules of operation of this institution: staff and salaries, form of remuneration, job responsibilities of staff, accounting policy of the budget institution. It should be noted that the head of the budget institution forms its accounting policy in accordance with applicable law.

The regulatory framework for accounting in budgetary institutions is in the process of reform and constant change. The changes are due to the globalization processes taking place in the world and Ukraine's desire to join them.

Key words: budgetary institution, public sector, regulatory and legal support of accounting.

Постановка проблеми у загальному вигляді i iї зв'язок 3 важливими науковими і практичними завданнями. При першій згадці про бюджетні установи у нашій уяві виникають дитячі садочки, школи, коледжі, вищі учбові заклади, державні лікувальні заклади, установи культури, військового комплексу, захисту внутрішнього правопорядку у державі.

Бюджетні установи становлять значну частку суб’ єктів господарювання України 3 важливим соціальним призначенням. Особливістю їх діяльності $є$ фінансування господарських процесів за рахунок коштів відповідних бюджетів. Власне особливості їх фінансування і зумовлюють назву таких установ. Наявність спеціальних коштів не змінює статусу цих установ, оскільки можливість отримання таких коштів зумовлена діяльністю з використання ресурсів, отриманих за рахунок бюджетних коштів.

Не зважаючи на джерела фінансування, ці установи функціонують як цілісний господарюючий суб'єкт і мають відповідну організаційну структуру. Діяльність установ державного сектору є чітко регламентованою. Але така регламентація ніяким чином не перекреслює потребу в застосуванні елементів методу управлінського обліку. Налагодження управлінського обліку у бюджетному секторі економіки зумовлене обмеженістю фінансових ресурсів і необхідністю їхнього раціонального використання.

Останні роки відбувалися зміни у бюджетному обліку. Передумовою цих змін було прийняття відповідних нормативних документів:

- Постанова КМУ від 16.01.2007 p. № 34 «Про затвердження Стратегії модернізації системи бухгалтерського обліку в державному секторі України на 20072015 pp.» [1];

- Розпорядження КМУ від 20.06.2018 р. № 437-р «Про схвалення Стратегії модернізації системи бухгалтерського обліку та фінансової звітності в державному секторі на період до 2025 року» [2].

В рамках реалізації Стратегії модернізації системи бухгалтерського обліку в державному секторі було розроблено і прийнято 19 Національних положень (стандартів) бухгалтерського обліку в державному секторі, План рахунків бухгалтерського обліку в державному секторі, внесено необхідні зміни до Бюджетного кодексу України та Закону України «Про бухгалтерський облік та фінансову звітність в Україні», а також до іншого бюджетного законодавства, сформовано порядок організації роботи бухгалтерських служб та головних бухгалтерів бюджетних установ тощо. Однак, наведені вище позитивні результати модернізації обліку в державному секторі не вплинули на вирішення нагальної проблеми бюджетного обліку - формування підсистеми 
управлінського обліку в бюджетних установах. Саме ця підсистема обліку виходить на перший план і потребує подальшого вивчення.

Аналіз останніх досліджень, у яких започатковано вирішення проблеми. Питання організації управлінського обліку в бюджетних установах висвітлені у працях вітчизняних науковців, серед яких: Атамас П.Й. [3], Голов С.В. [4], Джога Р.Т. [5], Канєва Т.В. [6], Клименко О.М. [7], Кондратюк I.О. [8], Кондрашова Т.М. [9], Левицька С.О. [10], Пігош В. [11], Свірко С.В. [12, 13], Чечуліна О.О. [14], Чумаченко М.Г. [15] та інші. Не зважаючи на значну кількість наукових праць фахівців у цій сфері, питання $є$ актуальним та потребує подальших досліджень.

Цілі статті. Метою написання статті є висвітлення теоретичних підходів до організації управлінського обліку в бюджетних установах та розробка пропозицій щодо налагодження процесу управлінського обліку в установах державного сектору.

Виклад основного матеріалу дослідження 3 повним обгрунтуванням отриманих наукових результатів. Організація управлінського обліку в бюджетних установах повинна забезпечити ефективну роботу всієї бюджетної структури при використанні обмежених державних ресурсів.

Оскільки облік у бюджетних установах, як і облік інших суб’єктів господарювання (мається на увазі ті суб'єкти господарювання, які функціонують виключно за рахунок власних коштів і основною метою діяльності яких є отримання прибутку) регламентується Законом України «Про бухгалтерський облік та фінансову звітність в Україні» [16], то питання організації управлінського обліку належать до компетенції керівника такої бюджетної установи.

Слід відмітити, що управлінський облік, як облік, що продукує інформацію для прийняття управлінських рішень, завжди був притаманний для бюджетної установи. Це, перш за все, пов'язане з постійним обмеженням бюджетних ресурсів та необхідністю вирішувати першочергові питання виживання бюджетної структури.

Сьогоднішній стан бюджетної сфери має низку проблем: у багатьох випадках розширений штат працівників і обмеженість фінансових ресурсів. Розширення штату працівників грунтувалося на збільшенні обсягів бюджетних послуг, які мали надавати громадянам. Особливістю бюджетних послуг була їх повна або часткова безоплатність та встановлення гарантованого мінімуму для населення. Безоплатність бюджетних послуг і низька оплата праці у цій сфері зумовила низьку їх якість. Держава поставила завдання покращити якість бюджетних послуг. Одним із шляхів такого якісного покращення вбачалося зменшення чисельності працівників бюджетної сфери i збільшення оплати праці тим, хто залишився. Але різке скорочення працівників бюджетних установ має негативну соціальну складову та поглиблює соціальну напругу в суспільстві. Крім реального скорочення часто має місце імітація такого процесу. Власне мова йде про анонсування скорочення одних структур і через певний проміжок часу виникнення інших структур, які дублюють функції попередників, або тих, які вже давно працюють у цій сфері. Все це не призводить до покращення фінансового стану бюджетної системи з ії обмеженими фінансовими ресурсами у доволі небагатій країні.

Зазначені вище аргументи вказують на необхідність організації управлінського обліку у бюджетній установі з метою прийняття оптимальних управлінських рішень.

Налагодження управлінського обліку в установі належить до компетенції керівника [16], а вже організацією такого обліку буде займатися головний бухгалтер установи.

Нормативної регламентації управлінського обліку на рівні держави немає, тому система організації обліку буде відрізнятися у кожній установі. Разом з тим, потрібно зазначити, що бюджетний облік $є$ надзвичайно регламентованим і спрямованим на раціональне використання бюджетних коштів.

Організація управлінського обліку в установі передбачає комплекс дій відповідальної особи (головного бухгалтера) по розробці методики ведення обліку, 
технічного забезпечення отримання аналітичних даних та побудову системи організаційних відносин для забезпечення надходження аналітичних даних.

Базовим моментом організації управлінського обліку в установі є розробка методики ведення такого обліку. Оскільки сенс управлінського обліку полягає в прийнятті виваженого рішення відповідно до базових принципів функціонування всього бюджетного сектору економіки, то перед головним бухгалтером постає питання організації роботи з інформаційними потоками в установі.

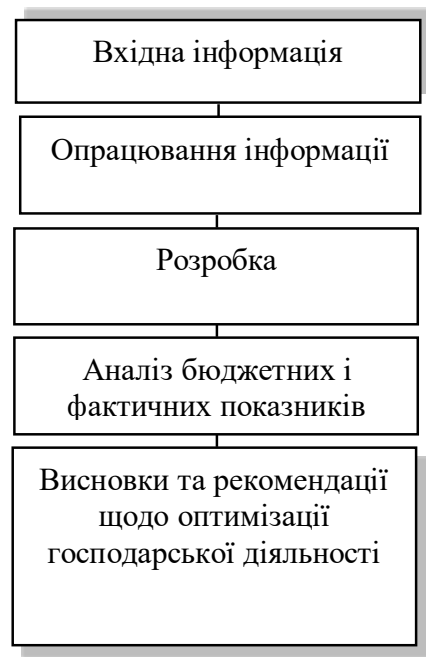

Рис. 1. Організація роботи з інформаційними потоками в бюджетній установі

Фактично алгоритм роботи з інформаційними потоками є надзвичайно простий i характерний для будь-якої господарської структури.

Розробка методики ведення управлінського обліку повинна забезпечити вирішення окремих питань, які необхідно буде затвердити внутрішнім розпорядчим документом установи. Серед цих питань наступні:

- визначення центрів відповідальності з відповідальними особами. У якості центів відповідальності може бути освітня послуга у навчальному закладі, медична послуга у лікувальному закладі, послуга по оформленню документа та інші види діяльності установ державного сектору. Крім того, може бути окремо виділена діяльність самостійного структурного підрозділу установи, якщо виникають різні думки щодо доцільності його функціонування;

- визначення статей витрат у розрізі центрів відповідальності;

- визначення порядку віднесення витрат на центри відповідальності з чітким механізмом розподілу накладних витрат;

- визначення механізму розподілу доходів між центрами відповідальності;

- розробка критеріїв прийняття управлінських рішень у розрізі відповідних центрів відповідальності.

3 метою поглиблення методологічних підходів до організації управлінського обліку доцільно розробити систему рахунків та інформацію, яку вони надають у розрізі конкретних центів відповідальності. Чітка регламентація бюджетного обліку передбачає узгодження підходів до організації управлінського обліку з нормативною базою. Мова йде про нормування витрат на окремі види послуг установ державного сектору.

Після визначення методики ведення управлінського обліку постає питання налагодження технічного процесу його здійснення. У цьому напрямку необхідно розробити засоби відображення результатів обліку. Мова йде про перелік таблиць, у яких можна буде узагальнити оброблену інформацію у чітко визначених рамках. Зазвичай в управлінському обліку для цих потреб використовують бюджети. Бюджети представляють собою комплекс планових показників, розроблених на основі діючих нормативних документів, що регулюють діяльність установ бюджетної сфери. Так, у 
сфері освіти, це можуть бути стандарти освіти, які передбачають певні години на підготовку фахівців на норми оплати праці викладацького складу. У медичній сфері мова буде йти про норми рівня медичного забезпечення пацієнтів та нормативні витрати на надання медичних послуг. Тобто має бути розроблений макет кінцевого бюджету витрат окремого центру відповідальності та макети підсистеми різних допоміжних бюджетів, які деталізують інформацію, представлену в основному бюджеті. Витратна частина бюджетів повинна передбачати відповідні джерела покриття цих витрат. Тому важливим кроком є формування бюджетів надходжень у розрізі центів відповідальності. Крім того повинні бути зазначені контрольні суми для узгодження системи бюджетів.

Після вирішення методичних і технічних питань бухгалтер (головний бухгалтер) має розписати джерела надходження вихідної інформації (табл. 1).

Таблиця 1

Джерела надходження інформації про діяльність центру відповідальності

Центр відповідальності: надання послуг копіювання (як приклад)

\begin{tabular}{|c|c|c|c|c|}
\hline $\begin{array}{c}\text { Об’єкт } \\
\text { дослідження }\end{array}$ & $\begin{array}{c}\text { Складові } \\
\text { об’єкта } \\
\text { дослідження }\end{array}$ & $\begin{array}{l}\text { Первинні } \\
\text { документи }\end{array}$ & $\begin{array}{c}\text { Структурний } \\
\text { підрозділ, посадова } \\
\text { особа, яка } \\
\text { відповідальна за } \\
\text { надання інформаціі }\end{array}$ & $\begin{array}{c}\text { Термін надходження у } \\
\text { бухгалтерію }\end{array}$ \\
\hline \multirow{5}{*}{ Витрати } & $\begin{array}{l}\text { Матеріальні } \\
\text { витрати }\end{array}$ & $\begin{array}{c}\text { Накладна, акт на } \\
\text { списання } \\
\text { матеріальних } \\
\text { цінностей, } \\
\text { лімітно-забірна } \\
\text { картка, вимога }\end{array}$ & $\begin{array}{c}\text { Склад матеріальних } \\
\text { цінностей, завідувач } \\
\text { складом }\end{array}$ & $\begin{array}{c}\text { Електронна копія - } \\
\text { відразу ж після } \\
\text { здійснення операції, } \\
\text { паперовий варіант - } \\
\text { протягом 3-х днів } \\
\text { після здійснення } \\
\text { операції. Паперова } \\
\text { копія первинних } \\
\text { документів додається } \\
\text { одночасно із } \\
\text { матеріальним звітом } \\
\text { матеріально- } \\
\text { відповідальної особи }\end{array}$ \\
\hline & $\begin{array}{c}\text { Заробітна } \\
\text { плата }\end{array}$ & $\begin{array}{l}\text { Акт виконаних } \\
\text { робіт, } \\
\text { розрахункова } \\
\text { відомість }\end{array}$ & $\begin{array}{c}\text { Планово- } \\
\text { економічний відділ, } \\
\text { бухгалтерія, відділ } \\
\text { кадрів; бухгалтер по } \\
\text { заробітній платі } \\
\end{array}$ & $\begin{array}{c}\text { По завершенні } \\
\text { господарської } \\
\text { операції }\end{array}$ \\
\hline & $\begin{array}{c}\text { Відрахування } \\
\text { на соціальні } \\
\text { заходи } \\
\end{array}$ & $\begin{array}{c}\text { Довідка- } \\
\text { розрахунок }\end{array}$ & $\begin{array}{c}\text { Бухгалтерія; } \\
\text { бухгалтер по } \\
\text { заробітній платі }\end{array}$ & $\begin{array}{c}\text { По завершенні } \\
\text { господарської } \\
\text { операції }\end{array}$ \\
\hline & Амортизація & $\begin{array}{c}\text { Довідка- } \\
\text { розрахунок }\end{array}$ & $\begin{array}{c}\text { Бухгалтерія; } \\
\text { бухгалтер з обліку } \\
\text { основних засобів }\end{array}$ & $\begin{array}{c}\text { Щомісяця, не пізніше } \\
\text { 30-го числа }\end{array}$ \\
\hline & Інші витрати & $\begin{array}{c}\text { Рахунки, акти } \\
\text { виконаних робіт, } \\
\text { накладні, товарні } \\
\text { чеки та інші } \\
\text { виправдні } \\
\text { документи, } \\
\text { довідки- } \\
\text { розрахунки }\end{array}$ & $\begin{array}{c}\text { Бухгалтерія, } \\
\text { планово- } \\
\text { економічний відділ, } \\
\text { обслуговуючі } \\
\text { господарства; } \\
\text { бухгалтер по } \\
\text { розрахунках, } \\
\text { економіст, головний } \\
\text { енергетик, головний } \\
\text { інженер }\end{array}$ & $\begin{array}{c}\text { Щомісяця, не пізніше } \\
\text { 30-го числа }\end{array}$ \\
\hline
\end{tabular}

Обов’язки надання інформації можуть бути закріплені у відповідних посадових інструкціях.

Висновки. Організація управлінського обліку є творчим процесом в установі. Основне призначення управлінського обліку - прийняття об'єктивного управлінського 
рішення. Саме це є надзвичайно актуальним завданням в умовах обмежених бюджетних коштів. Нами було виділено три основних моменти, на які необхідно зробити акцент при організації управлінського обліку в бюджетній установі: методичний, технічний, організаційний. Також у роботі в загальному окреслено ті питання, які повинні бути вирішені на кожному етапі організаційного процесу. Перелік питань, які мають бути висвітлені на кожному етапі організаційного процесу є індивідуальними для кожної установи і основне їх завдання полягає у забезпеченні аналітичного персоналу всією важливою інформацією на етапі прийняття управлінського рішення.

\section{Список бібліографічного опису}

1. Постанова Кабінету Міністрів України «Про затвердження Стратегії модернізації системи бухгалтерського обліку в державному секторі на 2007-2015 роки» від 16.01.07 p. № 34. URL: https://zakon.rada.gov.ua/laws/show/34-2007$\%$ D0\% BF (дата звернення 05.05.2020).

2. Розпорядження КМУ від 20.06.2018 р. № 437-р «Про схвалення Стратегії модернізації системи бухгалтерського обліку та фінансової звітності в державному секторі на період до 2025 року. URL: https://zakon.rada.gov.ua/laws/show/437-2018-\%D1\%80 (дата звернення 05.05.2020).

3. Атамас П.Й. Управлінський облік: Навчальний посібник. К. : Центр навчальної літератури, 2006. 440 с.

4. Голов С.Ф. Управлінський облік. К. : Лібра, 2003. 704 с.

5. Джога Р.Т. Бухгалтерський облік у бюджетних установах. Навчальний посібник. Київ: Центр навчальної літератури, 2003. 284 с.

6. Канєва Т.В. Облік доходів і видатків спеціального фонду бюджетних установ : автореф. дис. ... канд. ек. наук : спец. 08.06 .04 «Бухгалтерський облік, аналіз і аудит». Київ, 2002. 21 с.

7. Клименко О.М., Полякова О.В. Удосконалення управління витратами в бюджетних установах шляхом впровадження управлінського обліку. Науковий вісник ЧДІЕУ № 2 (22), 2014. URL: file:///D:/Downloads/27391-492041-SM\%20(2).pdf (дата звернення 05.05.2020).

8. Кондратюк I.О. Окремі категорії управлінського обліку в бюджетному процесі. Вісник Хмельницького національного університету. 2007. № 3. С. 227-229.

9. Кондрашова Т. М. Управлінський облік в державних вищих навчальних закладах [Текст]: дис.... канд. екон. наук : 08.00.09. Київ. нац. екон. ун-т ім. В.Гетьмана. К., 2007. 20 с.

10. Левицька С.О. Облік та контроль діяльності неприбуткових організацій: Монографія. Рівне: НУВГП, 2005. 347 с.

11. Пігош В. Формування системи управлінського обліку в державних вищих навчальних закладах. Соціальноекономічні проблеми $\mathrm{i}$ держава. 2012. Вип. 2 (7). $\mathrm{C}$. 170-179. URL: http://sepd.tntu.edu.ua/images/stories/pdf/2012/12pvavnz.pdf (дата звернення 05.05.2020).

12. Свірко С.В. Концептуалізація управлінського обліку в бюджетних установах України. Вчені записки. Науковий збірник. Вип. 14. Ч. 2. К. : КНЕУ, 2012. С.167-173.

13. Свірко С.В. Передумови виникнення фінансового та управлінського обліку в бюджетних установах України. Фінанси, облік і аудит. Збірник наукових праць. № 27 (1). К. : КНЕУ, 2016. С. 244-259.

14. Чечуліна О.О. Світові тенденції та перспективи розвитку державного фінансового контролю. Фінансовий контроль. 2013. № 11. С. 28-30.

15. Чумаченко Н.Г. Развитие управленческого учета в Украине. Світ бухгалтерського обліку. 1998. № 10. С. 2.

16. Закон України «Про бухгалтерський облік та фінансову звітність в Україні» від 16.07.1999 р. №996 -XIV. URL: https://zakon.rada.gov.ua/laws/show/996-14 (дата звернення 05.05.2020).

\section{References}

1.Postanova Kabinetu Ministriv Ukrainy «Pro zatverdzhennia Stratehii modernizatsii systemy bukhhalterskoho obliku v derzhavnomu sektori na 2007-2015 roky» vid 16.01.07 r. № 34. URL: https://zakon.rada.gov.ua/laws/show/34-2007$\% \mathrm{D} 0 \% \mathrm{BF}$ (data zvernennia 05.05.2020).

2.Rozporiadzhennia KMU vid 20.06.2018 r. № 437-r «Pro skhvalennia Stratehii modernizatsii systemy bukhhalterskoho obliku ta finansovoi zvitnosti v derzhavnomu sektori na period do 2025 roku. URL: https://zakon.rada.gov.ua/laws/show/437-2018$\%$ D1\%80 (data zvernennia 05.05.2020).

3.Atamas P.Y. Upravlinskyi oblik: Navchalnyi posibnyk. K. : Tsentr navchalnoi literatury, 2006. $440 \mathrm{~s}$.

4.Holov S.F. Upravlinskyi oblik. K. : Libra, 2003. 704 s.

5.Dzhoha R.T. Bukhhalterskyi oblik u biudzhetnykh ustanovakh. Navchalnyi posibnyk. Kyiv: Tsentr navchalnoi literatury, 2003. $284 \mathrm{~s}$.

6.Kanieva T.V. Oblik dokhodiv i vydatkiv spetsialnoho fondu biudzhetnykh ustanov : avtoref. dys. ... kand. ek. nauk : spets. 08.06.04 «Bukhhalterskyi oblik, analiz i audyt». Kyiv, 2002. $21 \mathrm{s.}$

7.Klymenko O.M., Poliakova O.V. Udoskonalennia upravlinnia vytratamy v biudzhetnykh ustanovakh shliakhom vprovadzhennia upravlinskoho obliku. Naukovyi visnyk ChDIEU № 2 (22), 2014. URL: file:///D:/Downloads/27391-492041-SM\%20(2).pdf (data zvernennia 05.05.2020).

8. Kondratiuk I.O. Okremi katehorii upravlinskoho obliku v biudzhetnomu protsesi. Visnyk Khmelnytskoho natsionalnoho universytetu. 2007. № 3. S. 227-229.

9.Kondrashova T. M. Upravlinskyi oblik v derzhavnykh vyshchykh navchalnykh zakladakh [Tekst]: dys.... kand. ekon. nauk : 08.00.09. Kyiv. nats. ekon. un-t im. V.Hetmana. K., 2007. 20 s.

10. Levytska S.O. Oblik ta kontrol diialnosti neprybutkovykh orhanizatsii: Monohrafiia. Rivne: NUVHP, 2005. 347s. 
11. Pihosh V. Formuvannia systemy upravlinskoho obliku v derzhavnykh vyshchykh navchalnykh zakladakh. Sotsialnoekonomichni problemy i derzhava. 2012. Vyp. 2 (7). S. $\quad$ 170-179. URL: http://sepd.tntu.edu.ua/images/stories/pdf/2012/12pvavnz.pdf (data zvernennia 05.05.2020).

12. Svirko S.V. Kontseptualizatsiia upravlinskoho obliku v biudzhetnykh ustanovakh Ukrainy. Vcheni zapysky. Naukovyi zbirnyk. Vyp. 14. Ch. 2. K. : KNEU, 2012. S.167-173.

13. Svirko S.V. Peredumovy vynyknennia finansovoho ta upravlinskoho obliku v biudzhetnykh ustanovakh Ukrainy. Finansy, oblik i audyt. Zbirnyk naukovykh prats. № 27 (1). K. : KNEU, 2016. S. 244-259.

14. Chechulina O.O. Svitovi tendentsii ta perspektyvy rozvytku derzhavnoho finansovoho kontroliu. Finansovyi kontrol. 2013. № 11. C. 28-30.

15. Chumachenko N.H. Razvytye upravlencheskoho ucheta v Ukrayne. Svit bukhhalterskoho obliku. 1998. № 10. S. 2.

16. Zakon Ukrainy «Pro bukhhalterskyi oblik ta finansovu zvitnist v Ukraini» vid 16.07.1999 r. №996 -XIV. URL: https://zakon.rada.gov.ua/laws/show/996-14 (data zvernennia 05.05.2020).

Дата подання публікації 02.06.2020 р.

\title{
УДК 657.1
}

Зеленко С.В., к.е.н., доцент

Zelenko S. Candidate of Economic Sciences, Associate Professor https://orcid.org/0000-0001-6074-1749

Писаренко Т.М., к.е.н., доцент

Pysarenko T. Candidate of Economic Sciences, Associate Professor

https://orcid.org/0000-0001-5018-0546

\section{ОЦІНКА НОРМАТИВНО-ПРАВОВОГО ЗАБЕЗПЕЧЕННЯ ОБЛІКУ ГОСПОДАРСЬКОЇ ДІЯЛЬНОСТІ БЮДЖЕТНИХ УСТАНОВ}

\author{
Луцький національний технічний університет
}

Діяльність бюджетних установ має свої особливості, які зумовлюють відповідну специфіку нормативного забезпечення облікового процесу в установах державного сектору. Метою написання статті $\epsilon$ проведення аналізу нормативно-правового забезпечення облікового процесу господарської діяльності бюджетних установ.

Нормативне забезпечення обліку - це комплекс нормативно-правових документів, які встановлюють єдині вимоги до ведення обліку у бюджетних установах.

Нормативна база є сукупним відображенням соціального, політичного, економічного, міжнародного впливів. У роботі розглянуто розвиток бюджетного обліку у 20-21 столітті. Виникнення різних форм власності після 1991 року призвело до суттєвих реформаційних процесів у бюджетному обліку.

Нормативно-правове забезпечення обліку у бюджетних установах можна поділити на три рівні: вищий рівень - регулює діяльність всіх суб’єктів господарювання, незалежно від форми власності; середній рівень - характеризується нормативним забезпеченням обліку діяльності установ державного сектору економіки; нижчий рівень - визначає перелік нормативів, які розроблені і функціонують виключно для забезпечення діяльності конкретної установи.

Основою ведення обліку є базові нормативи, які прийняті основним законодавчим органом України і визначають правові засади функціонування суб'єктів господарювання різних форм власності. Сюди відноситься Конституція України, Господарський Кодекс України, Цивільний Кодекс України, Трудовий Кодекс України, Кодекс про адміністративні правопорушення, Податковий Кодекс України. У цій нормативній ланці важливо виділити, Бюджетний кодекс України та Закон України «Про Про бухгалтерський облік та фінансову звітність в Україні».

Середній рівень нормативно-правового забезпечення включає у себе нормативні акти, які визначають методику обліку активів, пасив та господарських процесів у бюджетних установах.

Ознайомлення практикуючого бухгалтера з нормативами вищої і середньої ланок дає базові знання щодо діючої методики обліку у бюджетних установах. Але кожна бюджетна установа має свої особливості у побудові облікового процесу. Керівник бюджетної установи затверджує пакет внутрішніх документів, які визначають правила функціонування цієї установи: штат працівників та посадові оклади, форма оплати 